\title{
Two copepod species largely confused: Asterocheres echinicola (Norman, 1868) and A. violaceus (Claus, 1889). Taxonomical implications
}

\author{
M. Eugenia Bandera $\cdot$ Mercedes Conradi
}

Received: 4 February 2008 / Revised: 10 February 2009 / Accepted: 24 February 2009 / Published online: 29 March 2009

(C) Springer-Verlag and AWI 2009

\begin{abstract}
Due to its extremely brief description, Asterocheres echinicola (Norman, 1868) has been confused with some Asterocheres species such as Asterocheres suberitis Giesbrecht, 1897, Asterocheres parvus Giesbrecht, 1897 and Asterocheres latus (Brady, 1872). Furthermore, this species has been considered conspecific with Cyclopicera lata (Brady, 1872) and Asterocheres kervillei Canu, 1898. The objective of this paper is to study the syntypes of Asterocheres echinicola deposited in the Museum of Natural History of London together with abundant material from this and other institutions. Re-examination of these syntypes revealed that Asterocheres echinicola was conspecific with the currently known Asterocheres species, A. violaceus. Therefore, this latter species should be considered as a junior synonym of the former. The specimens described by Brady as Cyclopicera lata represent distinctively Asterocheres echinicola (=Asterocheres violaceus) and are identical to Sars's Ascomyzom parvum and to Giesbrecht's Asterocheres echinicola. We propose to rename Cyclopicera lata as Asterocheres latus (Brady, 1872), and raise Sars' Ascomyzon latus, a species which is different from Asterocheres echinicola (=Asterocheres violaceus) and from Asterocheres latus $(=$ Cyclopicera lata), as a new species. In this paper, we not only redescribe both species A. echinicola and A. latus, but also compare them with their previous descriptions, with the new material
\end{abstract}

Communicated by P. Funch.

M. E. Bandera $(\varangle) \cdot$ M. Conradi

Biodiversidad y Ecología de Invertebrados Marinos,

Departamento de Fisiología y Zoología,

Facultad de Biología, Universidad de Sevilla,

Reina Mercedes 6, 41012 Sevilla, Spain

e-mail: ebandera@us.es

M. Conradi

e-mail: mconradi@us.es available and with their congeners. The redescription of Asterocheres latus revealed new specific differences between this species and Asterocheres kervillei, a species considered as synonymous of Asterocheres latus for almost 40 years. We strongly recommend that these differences are sufficient to consider these two species different. Finally, we analyzed the implications of all these taxonomical changes with respect to the diversity of the hosts utilized by these copepods and their geographical distribution.

Keywords Siphonostomatoida $\cdot$ Asterocheres echinicola . Asterocheres violaceus $\cdot$ Asterocheres kervillei

\section{Introduction}

Norman (1868) described Asterocheres echinicola as Ascomyzon echinicola, on the basis of females living in the echinoderm Echinus esculentus Linneo, 1758 at Shetland Islands (UK). This description was very concise and devoid of any illustrations and, therefore, the identity of this species was not clear. Four years later, Brady described the species Cyclopicera lata which were living among algae in UK (Brady 1872). However, later on, the same author (Brady 1880) after a re-examination of type-specimens of Ascomyzon echinicola and studying more specimens of Cyclopicera lata collected from dredged material from Ireland, realized that these two species were conspecific. Brady's confusing suggestion of favouring the name of Cyclopicera lata to Ascomyzon echinicola in spite of the priority of the latter was followed by Thompson (1889, 1893) and Scott $(1893,1898,1900)$.

Brady's suggestion was corrected when Giesbrecht (1895) returned to the specific name of echinicola, naming his specimens collected from Naples as Cyclopicera 
echinicola. However, he misidentified them since, as Giesbrecht himself admitted after the examination of some specimens of A. echinicola sent to him by Scott, these specimens belonged to a new Asterocheres species: A. suberitis (Giesbrecht, 1897). This was not the only incidence when these two species were confused, since according to Stock and Gotto, the form referred to uncertainly as A. echinicola by Scott $(1898,1900)$ from the Clyde and Loch Fyne belongs to A. suberitis (Stock, 1967; Gotto, 1993).

Giesbrecht (1897) also stated the almost certain synonym between A. echinicola and Asterocheres kervillei, a species described by Canu (1898) in association with marine invertebrates in France. Nevertheless, he was not convinced because of the lack of A. echinicola males (Giesbrecht 1897). Seventy years later, Stock studying material of both sexes of these two species, concluded that they were conspecific with certain reservations: the length of the caudal rami, the slenderness of the body, and the ornamentation of the urosomal somites (Stock 1967). According to this author, these differences should be considered as intraspecific variability of A. echinicola. Surprisingly, Stock in his same work utilized similar characteristics - the length and shape of the siphon, the slenderness of the body, the length of the shortest seta of the mandibular palp and the armature of the fourth leg-to separate A. echinicola from A. parvus Giesbrecht, 1897.

Asterocheres echinicola has not only been confused with A. suberitis and A. kervillei but also with A. parvus (Sars, 1915, Klie, 1933; Lang, 1949). Thus, Sars, who does not believe in the conspecifity of Cyclopicera lata and Asterocheres echinicola, named his specimens of $A$. echinicola as Ascomyzon parvum. He also named Cyclopicera lata as Ascomyzon latum and stated that the specimens of Asterocheres boecki collected by Giesbrecht belong also to A. latum. It was Stock (1967) who demonstrated the conspecifity of A. echinicola and A. parvus illustrated by Sars (1915) and the validity of the species Asterocheres parvus described by Giesbrecht (1897). In fact, up to the present date, the most detailed description and illustrations of A. echinicola were performed by Sars under the name of Ascomyzon parvum.

Hamond in 1968 added more confusion to the identity of A. echinicola. He reported 16 specimens associated with the sponge Halichondria panicea (Pallas) collected from Norfolk in 1959 and compared them with A. echinicola (as Ascomyzon parvum Sars) and A. latus (Brady, 1880). Hamond claimed that there were two different forms among the Norfolk specimens: the latus-like and the echinicola-like with intermediate states. Therefore, and according to Hamond, A. latus should also be considered as a synonym of A. echinicola.

All of these difficulties in distinguishing Asterocheres echinicola from its congeners are due to inadequacies in its original description. Therefore, the study of Norman's species from type specimens is necessary to solve the taxonomic problems in this genus. This paper studies the syntypes of A. echinicola deposited in The Natural History Museum of London, together with abundant material from Norman's collection and others from later expeditions.

\section{Materials and methods}

The studied specimens come from both material loaned by various Musea and material collected by the authors. The studied material from The Natural History Museum of London $[\mathrm{BM}(\mathrm{NH})]$ included: Norman`s collection, some specimens collected by Hamond in 1988 in Great Britain; and those copepods from this country obtained during The SubAqua Expedition in 1966 sponsored by this institution and the University of London. Furthermore, we have examined material collected by Sars in Norway in 1915 and deposited in The Natural History Museum of the University of Oslo (ZMO) and some specimens collected by Stock in France in 1959 which were deposited in the Zoological Museum of the University of Amsterdam (ZMA).

The material collected by Dr. López-González and one of the authors (MC) was found at Tarifa (Spain) in 1991 associated with marine invertebrates. These invertebrates were individually collected in a plastic bag by SCUBA diving and immediately fixed in formaldehyde $8-10 \%$ in seawater. Symbiotic fauna was obtained by pouring the wash water through a $100 \mu \mathrm{m}$ net. The copepods were finally recovered from the sediment retained and preserved in $70 \%$ ethanol.

When the dissected specimens of the asterocherid species from the different musea were not sufficient to make a detailed description of some appendages, we dissected a specimen in lactic acid, prior to staining it with Chlorazol black E (Sigma $\left.{ }^{\circledR} \mathrm{C}-1144\right)$. It was then examined as temporary mounts in lactophenol and later on, sealed with Entellan as permanent mounts. This procedure was also followed with selected specimens obtained by the authors.

All figures were drawn with the aid of a camera lucida on a Leica DMLB differential interference microscope. All appendage segments and setation elements were named and numbered using the system established by Huys and Boxshall (1991). Mean body length of the copepod was measured from the anterior margin of the rostrum to the posterior margin of the caudal rami.

Material from Tarifa was deposited in The Natural History Museum of London (NHM) and in the collection of the research team Biodiversidad y Ecología de Invertebrados Marinos of the University of Seville (BEIM).

\section{Results}

Asterocheres echinicola (Norman, 1868)

Echinocheres violaceus Claus, 1889 


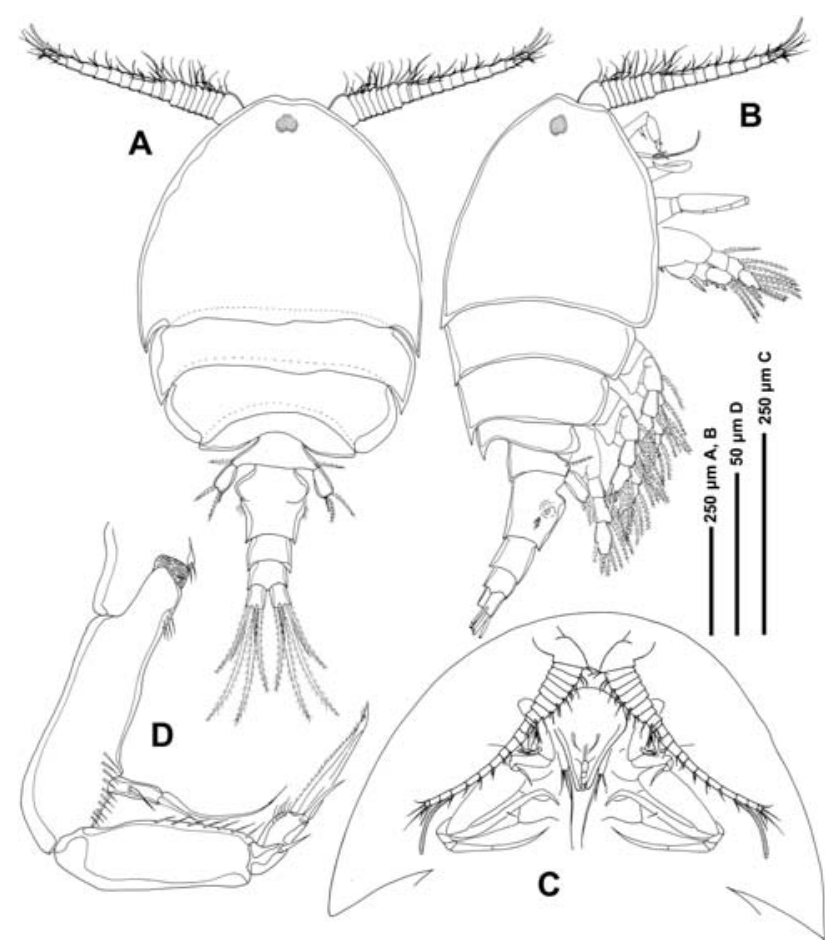

Fig. 1 Asterocheres echinicola (Norman, 1868) (female). a habitus, dorsal; b habitus, lateral; c oral appendages; $\mathbf{d}$ antenna

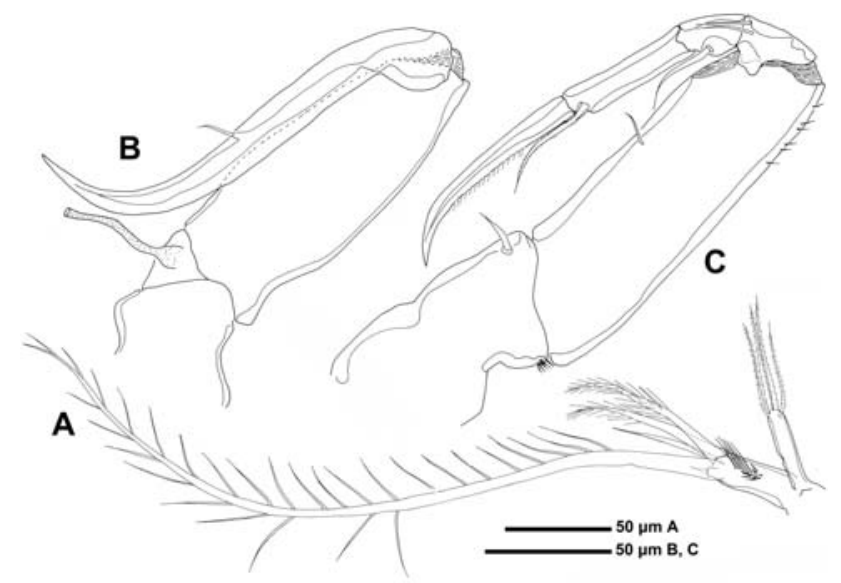

Fig. 2 Asterocheres echinicola (Norman, 1868) (female). a mandible, b maxillule, c maxilla

Ascomyzon thompsoni A. Scott, 1896

Asterocheres violaceus Giesbrecht, 1897

(Figures 1, 2, 10a)

Material examined

Three female syntypes (NHM 1911.11.8.M.2589) from Shetland; 5 females plus 4 males (BEIM COP-542), associated with the sea-urchin Paracentrotus lividus Lamarck, 1816, Tarifa Island (Southern Iberian Peninsula), $12 \mathrm{~m}$ depth, October 1991; 2 females (ZMO F21606), 9 females and 2 males (ZMO F21604) from Skjerjehaun (Norway) collected by
Sars; 4 females (ZMO F 21605) associated with Echinus elegans Düben and Koren, 1846, collected by Sars.

\section{Description}

\section{Adult female}

Body cyclopiform (Figs. 1a, b), slender with cephalothorax oval and cylindrical urosome. Mean body length $1,010 \mu \mathrm{m}$ $(980-1,050 \mu \mathrm{m})$ and maximum width $540 \mu \mathrm{m}$ (530$580 \mu \mathrm{m}$ ), based on three specimens. Ratio of length to width of prosome 1.25:1. Ratio of length of prosome to that of urosome 1.6:1.

Prosome, urosome, caudal rami and antennule as in the text and figures of Bocquet et al. (1963) and Giesbrecht (1899).

Antenna biramous (Fig. 1d), about $363 \mu \mathrm{m}$ long. Coxa unarmed, with few setules on inner margin; basis unarmed but ornamented with fine spinule rows. Exopod 1-segmented, slender, with small lateral seta and two terminal setae, one of them very long. Endopod 3-segmented; proximal segment elongated, ornamented with lateral row of fine spinules. Middle segment produced distally on medial side but articulating with distal segment proximally on lateral side; bearing one distal smooth seta. Third segment with stout distal claw, one smooth terminal seta, and a row of setules on inner margin.

Siphon (Figs. 1c, 10a) very short, reaching posterior margin of insertion of maxilla.

Maxillule bilobed (Fig. 2a); inner lobe (praecoxal endite) approximately as long as outer lobe (palp) but wider than outer lobe. Inner lobe ornamented with long setules and spinules medially; armed with five setae: two plumose, one smooth, one very short and smooth and one longer than the rest-about four and a half times longer-and ornamented with setules. Outer lobe armed with four barbed setae.

Maxilla two-segmented (Fig. 2b) but with transverse suture on syncoxa possibly marking plane of preacoxa-coxa fusion; praecoxal part bearing flaccid element medially, representing tubular extension of external opening of maxillary gland, and coxal part unarmed. Basis claw-like recurved at its end, armed with small seta in the middle of lateral margin.

Maxilliped five-segmented (Fig. 2c), comprising short syncoxa, long basis and three-segmented endopod. Syncoxa with one short seta distally; basis with setule on inner margin. First endopodal segment bearing two smooth distal setae; second endopodal segment with one smooth seta; third endopodal segment bearing terminal recurved claw and one barbed apical seta. Distal margin of claw with row of minute spinules.

Remaining appendages as in the description of Bocquet et al. (1963) and Giesbrecht (1899). 


\section{Adult male}

As described by Bocquet et al. 1963.

Remarks

Although Norman (1868) did not designate a holotype, the syntypes of Asterocheres echinicola are deposited in the NHM as one slide that contains three dissected Asterocheres specimens with their oral appendages, legs and urosomes mixed. These specimens belong to the same species, which is clearly recognizable by its short antennule, the extremely short siphon, its characteristic maxillule and the "rounded tip" of the fifth leg. However, this species does not correspond to the diagnostic characteristics that currently defined the species Asterocheres echinicola but to another known species described lately by Claus, Asterocheres violaceus (Claus, 1889). When Norman (1868) described A. echinicola, he provided the following characteristics: body shape similar to that of Ascomyzon lilljeborgi (Thorell)—which actually is Asterocheres siphonatus Giesbrecht-caudal rami twice as long as broad and the antennule 20-segmented (basal segments excessively short and the remaining somewhat longer but none of them as long as wide). Except for the length of the caudal ramus, which in A. violaceus is only one and a half times longer than wide and not twice as long as wide, the information that he provided was closer to A. violaceus than to A. echinicola. The confusion came later, when Brady considered the type specimens lent by Norman to be identical with Cyclopicera lata (Brady, 1880). It is very possible that Norman had mixed these two species since those Asterocheres collected later by him and labeled as A. echinicola had the diagnostic characteristics that currently defined A. echinicola. Nevertheless, since the syntypes of the A. echinicola had the diagnostic characteristics of Asterocheres violaceus, we have to consider the latter as a junior synonym of the former. Therefore, the specimen described by Brady as $C y c$ lopicera lata is in reality a distinct species from $A$. echinicola (=A. violaceus). No holotype was designated by Brady, but there is a female of this species recorded by Brady at Roker, a popular collecting locality for Brady, with no collection date deposited in the Hancock Museum (UK) (NEWHM-2.39.04). Unfortunately, we could not examine this unique slide with the entire copepod because the full Brady slide collection is currently in cabinets packed into sealed crates, which are stored in a climate-controlled warehouse while major construction work is carried out on the museum buildings (D. Gordon, personal communication). This collection will be available when the museum re-opens. Nevertheless, the examination of Brady's illustration of the urosome casts no doubts on its conspecificity with Sars' Ascomyzon parvum (1915) and with Giesbrecht's Asterocheres echinicola (1899). Furthermore, the specimens that Sars (1915) stated to be identical to Cyclopicera lata and described as Ascomyzon latum (re-examination of Sars' specimens; ZMO reg. no. F21601) are also a different species from $A$. echinicola $(=A$. violaceus) and from Cyclopicera lata. This species should therefore be given a new name since Cyclopicera lata will be named, by priority and from now on, as Asterocheres latus (Brady, 1872). We here redescribed A. latus (=Brady's Cyclopicera lata and Sars' Ascomyzon parvum and Giesbrecht's Asterocheres echinicola); and propose also to raise Sars' Ascomyzon latum as a new species, naming it as Asterocheres sarsi sp. nov., a species which will be fully described in a future work.

Asterocheres echinicola was poorly described and illustrated as Ascomyzon echinicola by Norman in 1868 and as Echinocheres violaceus by Claus in 1889. Later on, it was described and illustrated by Giesbrecht (1899) and Bocquet et al. (1963) under the name of Asterocheres violaceus (Claus, 1889). The population of this species found in Tarifa Island (Southern Spain) shows some discrepancies with the previous descriptions. (1) The antennary exopod has not two but three elements; Bocquet et al. missed one lateral seta; (2) The armature of the third segment of the antennal endopod consists of one apical seta, claw and lateral row of setules, and not two setae and one claw as illustrated by Bocquet et al.; (3) The inner lobe of the maxillule possesses five setae instead of the four setae illustrated by Giesbrecht in 1899. The longest seta is more than four times longer than the median setae and is ornamented with setules. Furthermore, the shortest seta is smooth and shorter than the setules which ornamented the endite of the maxillule. (4) Giesbrecht's illustration of the maxillule shows four smooth setae on the outer lobe and the specimens from Tarifa possess four barbed setae. (5) The maxilla has a flaccid element medially, representing a tubular extension of the external opening of maxillary gland on the proximal part of the syncoxa which was not illustrated or mentioned by previous descriptions. (4) Bocquet et al. in 1963 illustrated the maxilliped of male as possessing six segments with the two median devoid of setae or spines. The specimens from Tarifa have a five-segmented maxilliped with the following armature formula: $(1,1,2,1,1+$ claw $)$.

This species belongs to the Asterocheres species group characterized by possessing a 21-segmented antennule in females and a 1-segmented mandibular palp. This group is composed of only three species: A. minutus (Claus, 1889), A. bacescui (Marcus, 1965) and A. madeirensis Bandera et al., 2007.

Asterocheres bacescui and A. madeirensis can be separated from $A$. echinicola by the length of the siphon and the comparative size of the two lobes of the maxillule (Bandera et al. 2007; Marcus and Por 1960). The inner lobe of the maxillule is longer than the outer lobe for A. bacescui and A. madeirensis, while, the two lobes of $A$. echinicola are more 
or less similar in length. As for the siphon, A. echinicola possesses an oral cone shorter than the remaining two species.

Asterocheres minutus is the most similar Asterocheres species to A. echinicola. In fact, these two species are considered sibling species (Bocquet et al. 1963; Bocquet and Stock 1962; Gotto 1979). However, there are a number of differences that separate them, such as (1) the body length, A. minutus is much shorter than A. echinicola; (2) the exopod of the antenna is slightly longer in A. minutus; (3) the shortest seta of the inner lobe of the maxillule which is shorter in A. echinicola; (4) the shape of the apical part of the free segment of the fifth leg which is more rounded in A. echinicola; (5) A. minutus bears three terminal setae equal in length in the exopod of the fifth leg and A. echinicola possesses one short seta and two long setae (about twice as long as the shorter one).

\section{Host}

For long time, Asterocheres echinicola was considered as mainly symbiont with sponges, with its occurrence on Echinus being accidental. This reason was even used as argument by Brady in support of the name of Cyclopicera lata rather than Ascomyzon echinicola in spite of the priority of the latter. The current synonymy between Asterocheres echinicola and $A$. violaceus demonstrates that A. echinicola is a well-distributed Atlantic-Mediterranean species typically associated with a wide range of both echinoid and asteroid species (Humes 1986). Its occurrence on ophiurids is dubious and needs confirmation (Gotto 1993).

This copepod has been found in four species of asteroids, two belonging to the order Forcipulata, Marthasterias glacialis (Linnaeus, 1758) and Asterias rubens Linnaeus, 1758, and other two to the order Spinulosida, Porania pulvillus (O. F. Müller, 1776) and Crossaster papposus (Linnaeus, 1767) (as Solaster papposus) (Barel and Kramers 1977; Bresciani and Lützen 1962; Bocquet and Stock 1962; Bocquet et al. 1963). A total of eight echinoids serve as hosts to A. echinicola: Psammechinus miliaris (Gmelin, 1778), P. Microtuberculatus, Strongylocentrotus droebachiensis (O. F. Müller, 1776); Echinus esculentus Linnaeus, 1758; E. elegans; Paracentrotus lividus; Arbacia lixula (Linnaeus, 1758), and Sphaerechinus granularis (Bocquet and Stock 1962; Bocquet et al. 1963; Claus 1889; Giesbrecht 1897, 1899; Graeffe 1902; Norman 1868; Sars 1915; Stock 1960 , present record).

\section{Distribution}

Norway (Sars 1915), Sweden (Barel and Kramers 1977; Bresciani and Lützen 1962; Lang 1949), Great Britain (Norman 1868; Gooding 1957), France (Bocquet and Stock 1962; Bocquet et al. 1963; Stock 1960), Italy (Claus 1889;
Giesbrecht 1897, 1899; Graeffe 1902) and Spain (present record).

Asterocheres latus (Brady, 1872)

Cyclopicera lata Brady 1872, 1880

Asterocheres echinicola Giesbrecht, 1899

Ascomyzon parvum Sars, 1915

(Figures 3, 4, 5, 10)

Material examined

Two females (NHM 1911.11.8.47267-268; in alcohol) collected in Firth of Forth (Scotland) by Norman; eight females (NHM) 1911.11.8.47269-273; in alcohol) collected in Firth of Forth (Scotland) by Norman; 5 females (NHM 1911.11.8. 47262-266; in alcohol) collected in Firth of Forth (Scotland) by Norman; one female (ZMA Co. 100.565; in alcohol) collected among washings of sponges (Cliona sp) in Banyuls (France) at $90 \mathrm{~m}$ depth in 1959; eight females (NHM 1967.10.31.84; in alcohol) collected in Scilly Isles (England) during SubAqua Expedition in 1966 (The Natural History Museum and The University of London); four females (NHM 1968.1.30.11; slides 1, 2, 5 and 6) collected in Scilly Isles (England) during SubAqua Expedition in 1966 (The Natural History Museum and The University of London).

\section{Description}

\section{Adult female}

Body cyclopiform (Fig. 3a), with cephalothorax oval and cylindrical urosome. Total length $754 \mu \mathrm{m}$ and maximum width $392 \mu \mathrm{m}$. Ratio of length to width of prosome 1.3:1. Ratio of length of prosome to that of urosome 2.2:1 Prosome comprising cephalothorax fully incorporating first pedigerous somite and three free pedigerous somites. Somites bearing legs 2 and 3 broad; epimeral areas with posterolateral angles rounded (Fig. 3a). Each somite is slightly concealed under the preceding somite except for somite bearing leg 4 which is much smaller and narrower than preceding ones and mostly hidden by anterior segment. Dorsal cephalothoracic surface and free pedigerous somites ornamented with integumental pores and sensilla.

Urosome 4-segmented (Fig. 3b), comprising leg 5-bearing somite, genital double-somite and two free abdominal somites. All urosomites ornamented with flattened epicuticular scales (Fig. 10b, c). Leg 5-bearing somite wider than long. Genital double-somite about as long as wide; genital apertures bipartite, comprising lateroventrally located copulatory pore and dorsolaterally located gonopore. Lateral margin of double somite ornamented with rows of setules on distal third, posterior to genital apertures (Fig. 3b). Each genital area armed with two small setae. 
Fig. 3 Asterocheres latus (Brady, 1872) (female). a habitus, dorsal; b, urosome, dorsal; $\mathbf{c}$ antennule; $\mathbf{d}$ antenna

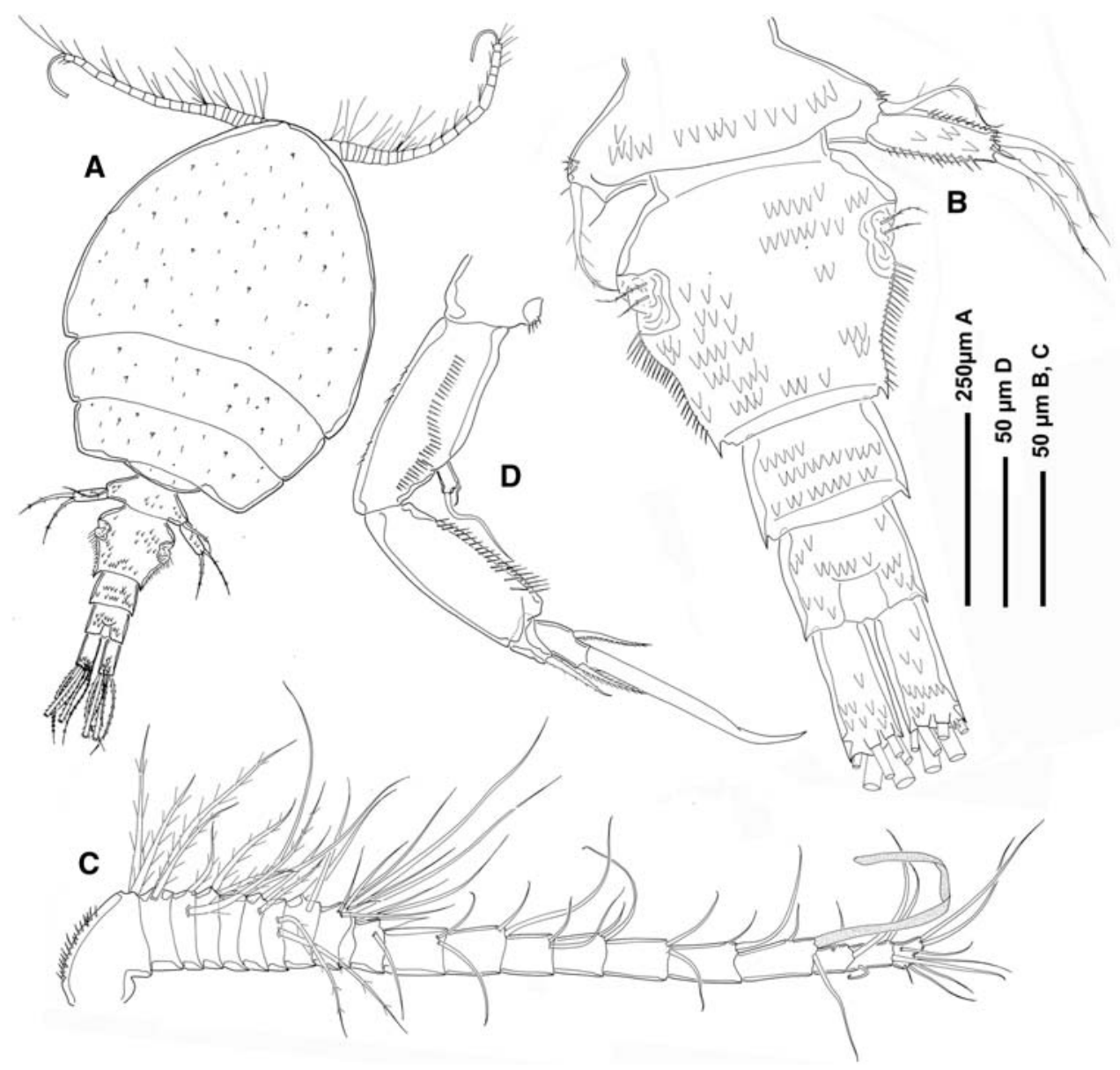

Antennule (Fig. 3c) 21-segmented, about $320 \mu \mathrm{m}$ long. Segmental fusion pattern as follows: 1 (I), 2 (II), 3 (III), 4 (IV), 5 (V), 6 (VI), 7 (VII), 8 (VIII), 9 (IX-XII), 10 (XIII), 11 (XIV), 12 (XV), 13 (XVI), 14 (XVII), 15 (XVIII), 16 (XIX), 17 (XX), 18 (XXI), 19 (XXII-XIII), 20 (XXIV-XXV), 21 (XXVI-XXVIII). Segments 1-8 with 2 setae each; segment 9 with 8 setae; segment 10 with 2 setae; segment 11 with one seta and one spine; segments 12-17 with 2 setae each; segment 18 with 2 setae plus an aesthetasc; segment 19 with 2 setae; segment 20 with 3 setae; segment 21 with 7 setae. Segment 10 (XIII) reduced, partly overlapped by distal expansion of compound segment 9 (IX-XII).

Antenna biramous (Fig. 3d), about $254 \mu \mathrm{m}$ long. Coxa unarmed, with few spinules. Basis unarmed but ornamented with spinule row. Exopod 1-segmented, short; with short seta and long terminal seta. Endopod 3-segmented; proximal segment elongated, ornamented with spinule rows on lateral margin; middle segment produced distally on medial side but articulating with distal segment proximally on lateral side, bearing one plumose terminal seta; distal segment with distal claw and 2 pinnated subterminal setae.

Siphon slender, about $185 \mu \mathrm{m}$ long, reaching between the insertion of maxilliped and leg 1 . 
Fig. 5 Asterocheres latus (Brady, 1872) (female). a leg 1, b leg 2, c leg 3, d leg 4

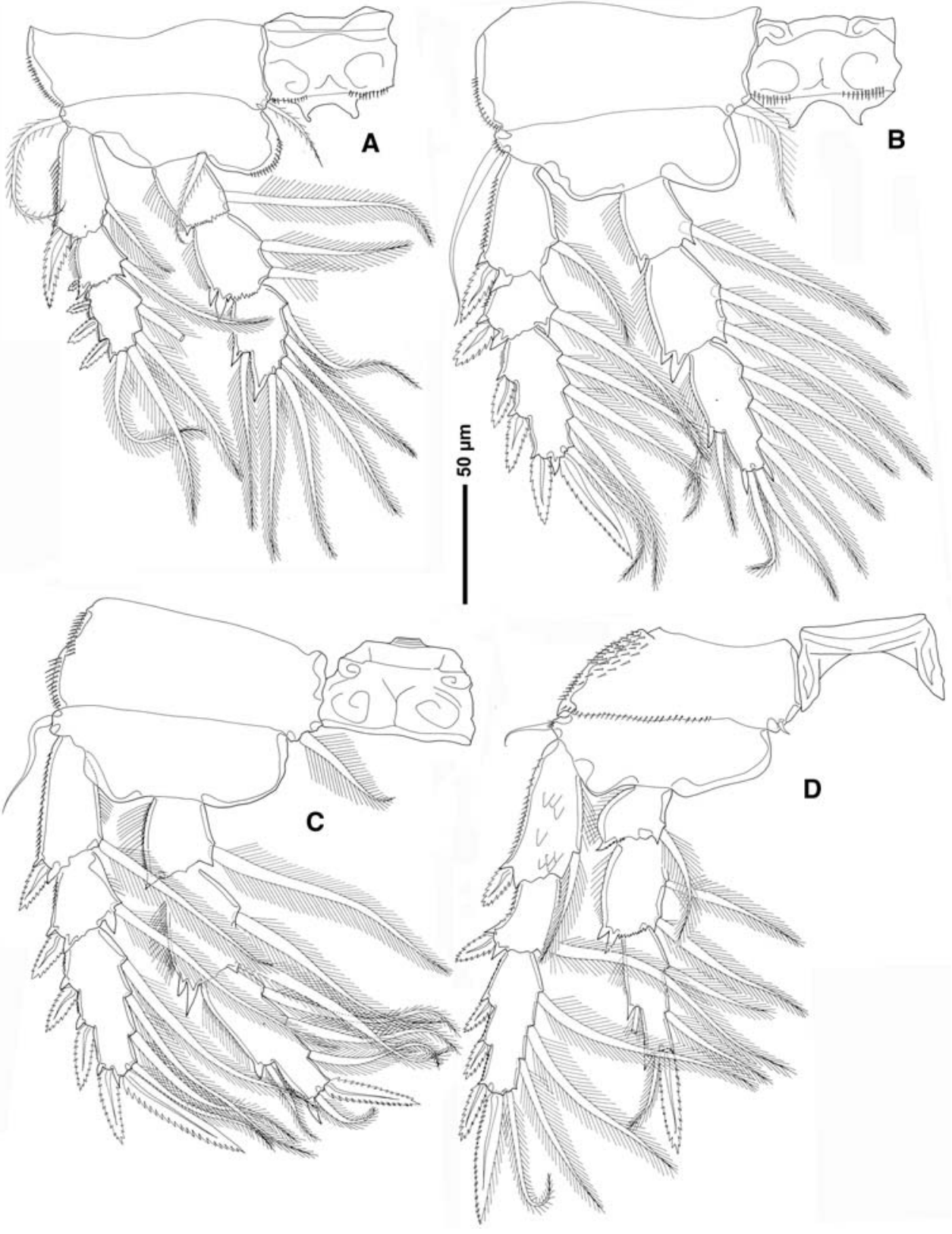

Mandible (Fig. 4a) comprising stylet-like gnathobase and slender 2-segmented palp. Proximal segment of palp longest, ornamented with spinules; distal segment shorter, ornamented with spinules and armed with 2 plumose unequal apical setae. Stylet located in oral cone, formed by labrum and labium. Stylet with elongated cavity in distal third.

Maxillule bilobed (Fig. 4b); inner lobe 3.2 times longer than outer lobe. Inner lobe ornamented with patch of spinules proximally and long setules medially; armed with five distal setae, one of them is minute and smooth. Outer lobe armed with three terminal setae and subterminal pinnated seta.

Maxilla (Fig. 4c) 2-segmented but with partial transverse surface suture on syncoxa possibly marking plane of praec- oxa-coxa fusion; preacoxal part bearing flaccid element medially representing tubular extension of external opening of maxillary gland. Coxal part unarmed but ornamented with spinules rows proximally and distally. Basis claw-like recurved at its end; armed with one minute seta and spinule rows in distal half.

Maxilliped 5-segmented (Fig. 4d), comprising short syncoxa, long basis and 3-segmented endopod. Syncoxa with short seta and patch of spinules distally. Basis with seta on inner margin and setule rows on outer margin. First endopodal segment bearing three smooth setae; second endopodal segment armed with plumose seta; and third endopodal segment bearing terminal claw plus subterminal pinnated seta. 
Swimming legs $1-4$ biramous (Figs. 5a-d), with 3-segmented rami. Intercoxal sclerites present in legs 1-4, ornamented with spinule rows in legs 1 and 2. Formula for armature as follows:

\begin{tabular}{lllll}
\hline & Coxa & Basis & Exopod & Endopod \\
\hline Leg 1 & $0-1$ & $1-1$ & I-1; I-1; III, 2, 2 & $0-1 ; 0-2 ; 1,5$ \\
Leg 2 & $0-1$ & $1-0$ & I-1; I-1; III, I, 4 & $0-1 ; 0-2 ; 1,2,3$ \\
Leg 3 & $0-1$ & $1-0$ & I-1; I-1; III, I, 4 & $0-1 ; 0-2 ; 1,1+\mathrm{I}, 3$ \\
Leg 4 & $0-1$ & $1-0$ & $1-1 ;$ I-1; III, I, 4 & $0-1 ; 0-2 ; 1,1+\mathrm{I}, 2$ \\
\hline
\end{tabular}

Fifth leg (Fig. 3b) with protopod incorporated into somite; outer basal seta displaced to laterodorsal surface. Free segment (exopod) elongated with two terminal setae and one hyaline setule (not a genuine seta). Outer and inner margins with spinules.

Sixth leg (Fig. 3b) represented by paired opercular plates closing off gonopores on genital double-somite; armed with two setae.

\section{Adult male}

Unknown.

Remarks

Asterocheres latus was poorly described and illustrated as Cyclopicera lata by Brady in 1872 with the following characteristics: the somite bearing leg 5 has a very small 1-segmented exopod with one basal (somite) and two terminal setae; the caudal rami are about as long as the anal somite; the antennule in the male possesses 17 segments, in the female 20 segments. His illustrations also show an antenna with a 1-segmented exopod with two terminal setae and a 2-segmented endopod with the setal formula: (2, $1+$ claw); and maxillule with the inner lobe twice as long as the outer lobe, both lobes armed with three terminal setae each. Eight years later, the same author erroneously considered this species identical to Asterocheres echinicola Norman, 1868 (see above) and under this name it was later described by Giesbrecht in 1899. This latter author, who studied material collected by Scott in the Firth of Forth, added the followings characteristics to the diagnosis of A. latus: the caudal rami is longer than the anal somite and 2.5 times longer than wide, the abdominal somites present irregular rows of "spinules", the longest seta of the mandibular palp is plumose, and the shape of the fifth leg is similar to that of A. boecki. Although Sars (1915) believed that Giesbrecht's A. boecki was identical to Cyclopicera lata, Stock (1967) demonstrated that both species were distinct and different also from Brady's original A. boecki. This latter author also claimed that Sars' Ascomyzon parvum (Sars, 1915) and those records of Klie (1933) and Lang (1949) were in reality a different species from Giesbrecht's original A. parvum (Stock, 1967). These records certainly referred to A. latus and until now, Sars' description of A. parvum provide us with the most detailed description and illustrations of A. latus. Giesbrecht was the first author in pointing out the presence of a third seta in the fifth leg (see illustrations of Giesbrecht 1899) which was confirmed by Sars (see illustrations of Sars 1915).

Our study of A. latus has revealed some differences with respect to its previous descriptions. For example, this species is commonly described as possessing 20 segments in the antennule of females, but the antennule really shows $21 \mathrm{seg}$ ments as illustrated by Huys and Boxshall in 1991. We agreed with Sars (1915) that the antennal endopod possesses three segments with the seta formula: $0,1,2+$ claw instead of the two segments illustrated by Brady (1872). The mandibular palp is 2-segmented as illustrated by Sars, but fully ornamented with spinules. The inner lobe of the maxillule has five setae (one of them minute) in contrast with three setae described by Giesbrecht (1899) and four setae illustrated by Sars. The maxilliped shows five segments as Sars illustrated but he did not show the ornamentation and armature present in this appendage. The genital area of the female presents two small setae. As Sars pointed out, the fifth leg bears three terminal setae, although one of them is "very small, delicate and difficult to see even under an oil-immersion lens" as Hamond (1968) described. The caudal setae are 2.5 times longer than wide as Giesbrecht described. The urosomites are ornamented with flattened epicuticular scales.

Asterocheres latus, which is included into the group of Asterocheres species with 21-segmented antennule in females, can be separated from 7 of the 19 species of the group by the body shape. While A. bacescui; A. ellisi Hamond, 1968, A. jeanyeatmanae Yeatman, 1970, A. lilljeborgi Boeck, 1859, A. lunatus Johnsson, 1998; A. simulans (Scott, T., 1898), and A. reginae Boxshall and Huys, 1994 possess a dorsoventrally flattened prosome, A. latus shows an oval cephalothorax and a cylindrical urosome (Marcus and Por 1965; Hamond 1968; Yeatman 1970; Ivanenko and Ferrari 2003; Johnsson 1998; Ivanenko 1997; Boxshall and Huys 1994).

The 2-segmented mandibular palp present in A. latus serves to separate it from A. minutus, A. echinicola and A. madeirensis whose mandibular palp has only one segment (Bandera et al. 2007; Claus 1889). Like the majority of Asterocheres species, A. latus possesses three terminal setae in the free segment of the fifth leg. However, A. uncinatus (Kritchagin, 1873) differs from this species by the possession of only two terminal setae in the exopod of this leg (Marcus and Por 1960 as Ascomyzon carausi).

The length of the caudal setae serves to distinguish A. tenuicornis Brady, 1910, A.suberitis, A. tenerus 
(Hansen, 1923), A. flustrae Ivanenko and Smurov, 1997, A. urabensis Kim, 2004, A. astroidicola Conradi et al., 2006 and A. intermedius (Hansen, 1923) from this species. A. latus possesses a caudal setae 2.5 longer than wide, while in contrast the caudal setae is 6 times longer than wide in A. tenuicornis, 1.5 times longer than wide in A. suberitis, and only slightly longer than wide in A. tenerus, A. flustrae, A. urabensis, A. astroidicola and A. intermedius (Eiselt, 1965; Hansen, 1923; Ivanenko and Smurov, 1997; Kim, 2004; Conradi et al., 2006). Asterocheres hirsutus Bandera et al., 2005 can be separated from A. latus from the ornamentation of the claws of the antenna, maxilla and maxilliped. While A. latus shows these claws naked or with a small row of spinules (only in that of the maxiliped), A. hirsutus presents these claws completely covered by spinules (see Figs. 1e, 2g, h; Bandera et al. 2005).

In 1898, Canu described a new Asterocheres species from the Normandy coasts. This species, Asterocheres kervillei, was so closely related to A. latus that Giesbrecht (1899) pointed out their possible conspecificity. The differences, according to Giesbrecht, were only: the shorter body length, slightly longer siphon and slightly shorter caudal rami of A. kervillei. He could not demonstrate that they were identical because of the lack of A. latus males in order to verify if the latter species had the same irregularities present in A. kervillei males on the first leg, the maxillipeds and on the genital somite. Later on, Stock (1967) studied material from both sexes and species and confirmed that these two species, A. latus and A. kervillei were identical, although he had certain reservations: the length of caudal rami, the slenderness of the body (above all at insertion of urosome level), and the ornamentation of the urosomal somites.

However and after the redescription of these two species (see below for the redescription of $A$. kervillei), we added the following differences between these species to those mentioned by Giesbrecht and Stock: (1) A. kervillei is shorter than A. latus; (2) The body of A. kervillei is more slender than that of A. latus; (3) The ornamentation of the body is different in both species: the urosomites of A. latus are covered by flattened epicuticular scales (Fig. 10b, c). However, those of A. kervillei are ornamented with spinules arranged in symmetric pattern in ventral view (Fig. 10d, e); (4) The caudal rami are 2.5 times longer than wide in A. latus and less than twice as long as wide in A. kervillei; (5) The segmental fusion pattern of antennule is also different: while in A. latus the last three segments of antennule have the formula 19 (XXII-XXIII), 20 (XXIV-XXV), 21 (XXVI-XXVIII); in A. kervillei is 19 (XXII), 20 (XXIIIXXIV), 21 (XXV-XXVIII); (6) The siphon is shorter in $A$. kervillei; (7) The genital area of A. latus shows two small plumose setae, whereas that of A. kervillei presents a small naked seta plus a spiniform element.
Although these two species have been considered synonymous for almost 40 years, we strongly believe that these differences are enough to consider these species as different.

Hosts

Although Brady found this species among algae in tidal pools or dredged from muddy sand, A. latus is found associated mainly with sponge species such as undetermined, Ciocalypta penicillus Bowerbank, 1864; Clathrina primordialis (Haeckel, 1872); Cliona sp.; Halichondria panicea (Pallas, 1766), Haliclona oculata (Pallas, 1766); Haliclona cinerea (Grant, 1826), and Grantia compressa (Fabricius, 1780), (Klie, 1933; Lang, 1949; Stock, 1960; Hamond, 1968; Schirl, 1973; Scott, 1893; Thompson, 1889, 1893). The record of Norman on Echinus is not valid for this species since it corresponds to A. echinicola (=A. violaceus).

\section{Distribution}

Sweden (Lang 1949), Netherlands (Sars 1915); United Kingdom (Brady 1872; Hamond 1968; Scott 1893, Thompson 1889, 1893, present record), France (Stock 1960; Schirl 1973).

\section{Asterocheres kervillei Canu, 1898}

(Figures 6, 7, 8, 9, 10d, e)

Material examined

Five females and three males (NHM 1996.747-754; in alcohol) collected at N. W. of Brancaster, Golf Club, Norfolk (Great Britain) by D. Hamond in 1988; one female and one male (NHM 2007.940-941) associated with the ascidian Pseudodistoma lyrnusense Pérès, 1952 at Isla Palomas (Tarifa Island, Southern Iberian Peninsula), $8 \mathrm{~m}$ depth, in August of 1991; ten females and three males (BEIM COP549) with the same sampling data as NHM 2007.940-941.

\section{Description}

\section{Adult female}

Body cyclopiform (Fig. 6a, b), slender with cephalothorax oval and cylindrical urosome. Mean body length $687 \mu \mathrm{m}$ $(640-730 \mu \mathrm{m})$ and greatest width $382 \mu \mathrm{m}(340-410 \mu \mathrm{m})$, based on four specimens. Ratio of length to width of prosome 1.2:1. Ratio of length of prosome to that of urosome 1.8:1. Prosome comprising cephalothorax fully incorporating first pedigerous somite and three free pedigerous somites. Epimeral areas of somites slightly pointed and clearly separated from the preceding somite. Segment bearing leg 4 smaller than preceding segment. Dorsal cephalothoracic shield and tergites of free pedigerous somites ornamented with few 
Fig. 6 Asterocheres kervillei Canu, 1898 (female). a habitus dorsal, b habitus lateral, c urosome, ventral, d urosome dorsal, e antennule

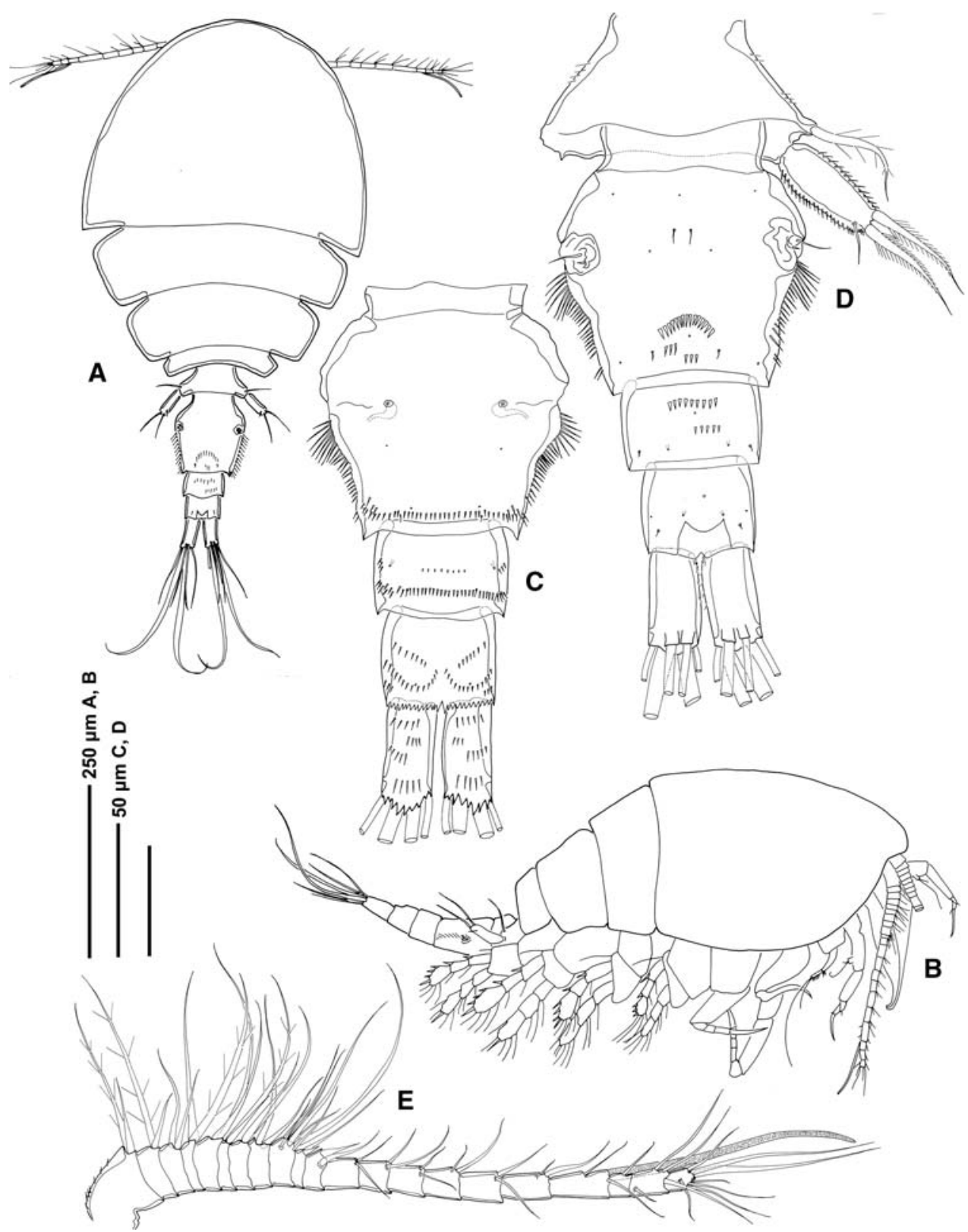

integumental pores and sensilla. Chitinous points and spines on the copepod's surface described by Canu, not observed.

Urosome (Fig. 6c, d) 4-segmented comprising leg fifth pedigerous somite, genital double-somite and two free abdominal somites. Somite bearing leg 5 (Fig. 6d) wider than long, with some spinules on its lateral surface. Posterior margins of anal segment and caudal rami ornamented with hyaline frills with more or less serrated margins. Genital double-somite and following somites provided with spinules arranged in regular pattern all around (Figs. 6c, $10 \mathrm{~d}, \mathrm{e})$. Integumental pores and sensilla present on urosomal somites. Genital double somite about as long as wide (width measured at small anterior rounded expansions), bearing genital apertures, paired gonopores located later- ally. Each genital area armed with smooth seta and spiniform element (Fig. 6b). Caudal rami almost twice longer than wide, armed with six setae; seta I absent, setae II-VII all arranged around posterior margin with setae II and VII slightly offset onto dorsal surface.

Antennule 21-segmented (Fig. 6e); segmental fusion pattern as follows: 1 (I), 2 (II), 3 (III), 4 (IV), 5 (V), 6 (VI), 7 (VII), 8 (VIII), 9 (IX-XII), 10 (XIII), 11 (XIV), 12 (XV), 13 (XVI), 14 (XVII), 15 (XVIII), 16 (XIX), 17 (XX), 18 (XXI), 19 (XXII), 20 (XXIII-XXIV), 21 (XXV-XXVIII). Segments $1-8$ with 2 setae each; segment 9 with 7 setae; segments $10-11$ with 1 seta and 1 small spine each; segments 12-17 with 2 setae each; segment 18 with 2 setae plus an aesthetasc; segment 19 with 1 seta; segment 20 with 


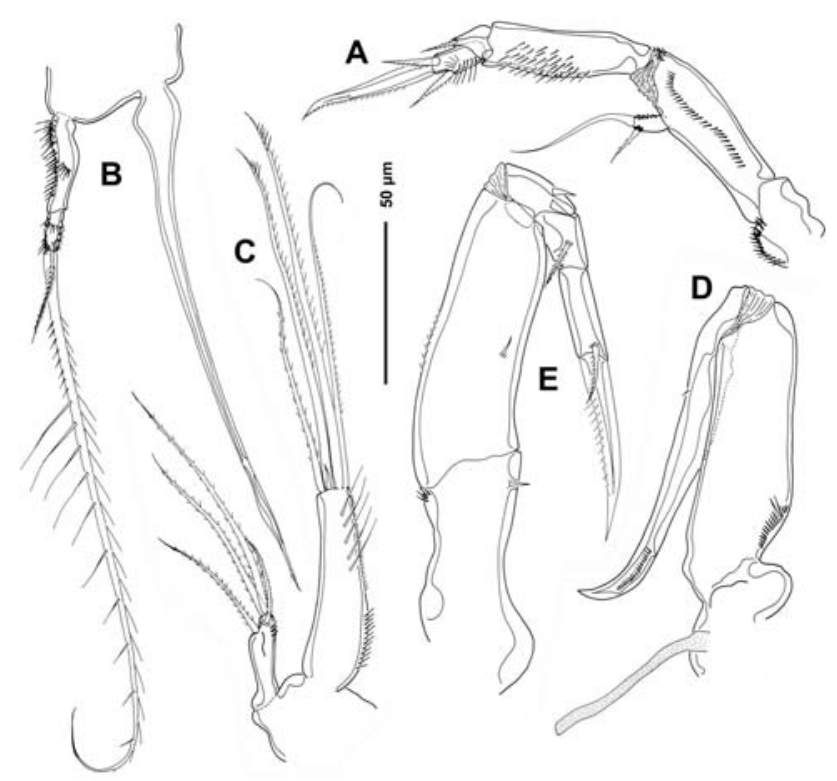

Fig. 7 Asterocheres kervillei Canu, 1898 (female). a antenna, b mandible, $\mathbf{c}$ maxillule, $\mathbf{d}$ maxilla, e maxilliped

4 setae and segment 21 with 7 setae. Segment 10 (XIII) reduced, partly overlapped by distal expansion of compound segment 9 (IX-XII).

Antenna biramous (Fig. 7a), about $185 \mu \mathrm{m}$ long; coxa unarmed, with row of setules; basis unarmed, with fine spinule rows. Exopod 1-segmented, ornamented with spinule rows, short, about 2.3 times longer than wide; with short barbed seta and long smooth terminal seta. Endopod 3-segmented; proximal segment elongated, unarmed but ornamented with tuft of setules on distal and medial parts. Middle segment produced distally on medial side but articulating with distal segment proximally on lateral side; bearing distal barbed seta. Third segment with distal claw and two pinnate setae; ornamented with row of fine setules laterally.

Mandible (Fig. 7b) comprising stylet-like gnathobase and slender 2-segmented palp. Stylet $160 \mu \mathrm{m}$ long, with spinules on distal part; located in oral cone formed by labrum and labium. Palp ornamented with rows of spinules laterally, medially and distally in both segments; armed with two plumose unequal apical setae (the longest is more than six times longer than the shortest). Siphon slender, $162 \mu \mathrm{m}$ long, reaching nearly to posterior margin of insertion of maxillipeds.

Maxillule bilobed (Fig. 7c); praecoxal endite more than twice as long as palp. Praecoxal endite ornamented with row of spinules laterally and row of long setules distally; armed with five distal setae, four of them long but unequal, ornamented with short spinules distally, and one short and naked seta. Palp armed with two subterminal and two terminal barbed setae and ornamented with several spinules distally.
Maxilla 2-segmented (Fig. 7d) but with partial transverse suture on syncoxa possibly marking plane of praecoxa-coxa fusion; praecoxal portion bearing flaccid aesthetasc-like element medially, representing tubular extension of external opening of maxillary gland. Coxa portion unarmed but ornamented with row of spinules and claw-like basis recurved on its end; bearing minute setule on proximal part and row of fine setules on distal part.

Maxilliped 5-segmented (Fig. 7e), comprising short syncoxa, long basis and distal subchela consisting of 3 free endopodal segments armed with distal claw-like element. Syncoxa with small inner distal seta and patch of fine spinules. Basis elongated with spinules laterally and setule on inner medial region. First endopodal segment bearing two naked setae, and the second with plumose seta. Third endopodal segment bearing recurved terminal claw plus additional apical plumose seta. Distal margin of claw provided with row of minute setules.

Swimming legs 1-4 biramous (Fig. 8a-d), with 3-segmented rami. Intercoxal sclerite present in legs $1-4$, ornamented with rows of spinules in leg 1-3. Formula for armature as follows:

\begin{tabular}{lllll}
\hline & Coxa & Basis & Exopod segments & Endopod segments \\
\hline Leg 1 & $0-1$ & $1-1$ & I-1; I-1; III, 2, 2 & $0-1 ; 0-2 ; 1,2,3$ \\
Leg 2 & $0-1$ & $1-0$ & I-1; I-1; III, I, 4 & $0-1 ; 0-2 ; 1,2,3$ \\
Leg 3 & $0-1$ & $1-0$ & I-1; I-1; III, I, 4 & $0-1 ; 0-2 ; 1,1+$ I, 3 \\
Leg 4 & $0-0$ & $1-0$ & I-1; I-1; III, I + 1, 3 & $0-1 ; 0-2 ; 1,1+$ I, 2 \\
\hline
\end{tabular}

Coxae of all legs ornamented with spinule rows laterally, as figured; coxal seta not present in leg 4. Outer spines of exopodal segments in legs 1-4 bilaterally serrated. Lateral margins of exopodal segments with minute serrations; lateral margins of endopodal segments with rows of setules. Second and third endopodal segments in legs 1-4 with small beak-shaped spiniform process distally.

Leg 5 (Fig. 6d) with protopodal segment incorporated into somite with outer seta located laterally; exopod slender, more than twice as long as wide, ornamented with rows of spinules laterally and armed with two plumose terminal setae and shorter naked subterminal seta.

Leg 6 (Fig. 6d) represented by paired opercular plates closing off gonopores on genital double somite; armed with plumose seta and spiniform element.

\section{Adult male}

Body cyclopiform, with oval prosome and cylindrical urosome (Fig. 9a). Mean body length $520 \mu \mathrm{m}(490-540 \mu \mathrm{m})$ and greatest width $253 \mu \mathrm{m}(238-280 \mu \mathrm{m})$, based on 3 specimens. Ratio of length to width of prosome 1.5:1. Ratio of length of prosome to that of urosome 1.9:1. Prosome 
Fig. 8 Asterocheres kervillei Canu, 1898 (female). a leg 1, b leg 2, c leg 3, d leg 4
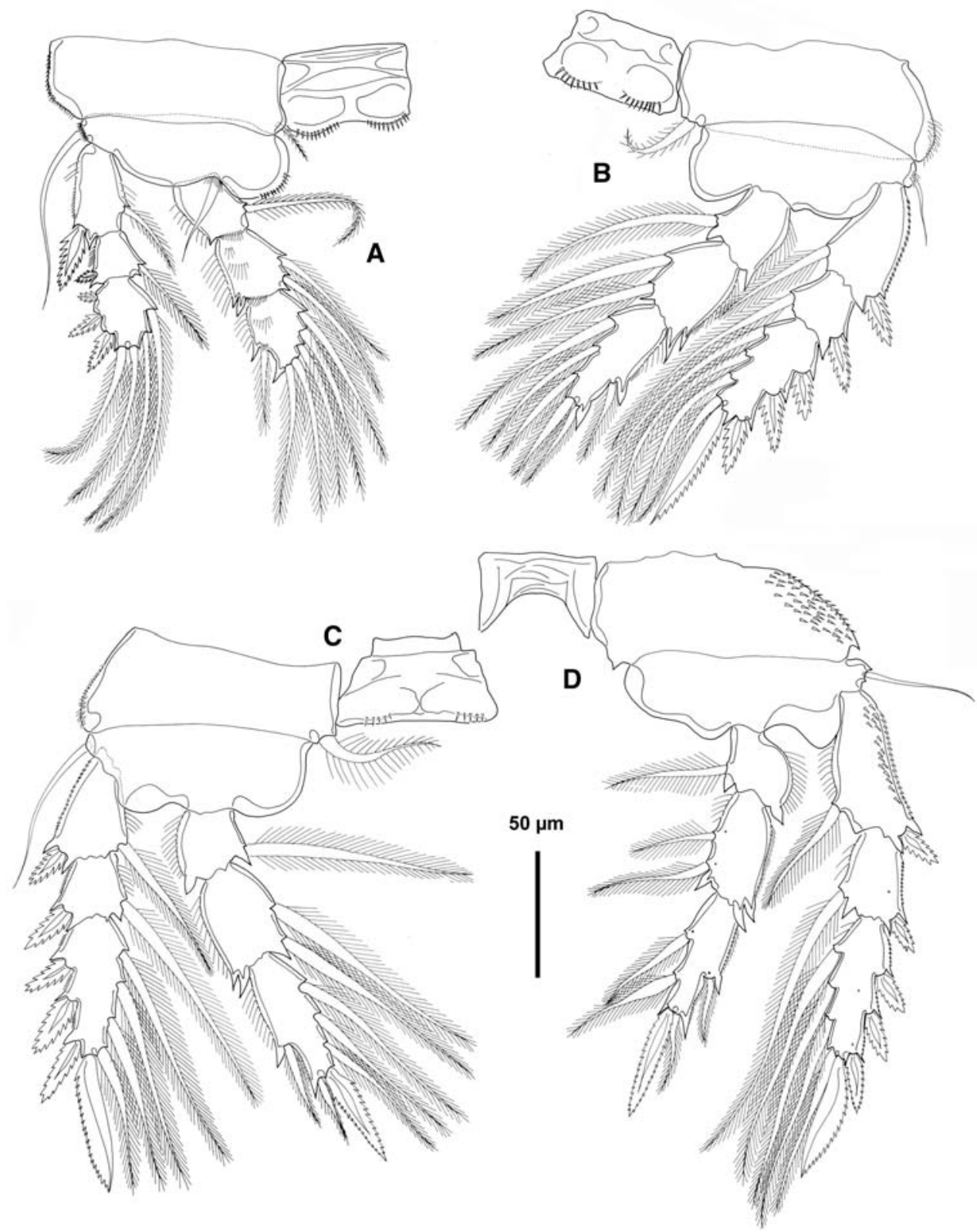

comprising cephalothorax fully incorporating first pedigerous somite and three free pedigerous somites. Dorsal cephalothoracic shield and free pedigerous somites ornamented with integumental pores and sensilla. Urosome 5-segmented (Fig. 9b), comprising fifth pedigerous somite, genital somite and three free abdominal somites. Posterior margin of anal segment and caudal ramus ornamented with hyaline frills with serrated free margins. Genital somite about 1.2 times wider than long, bearing genital apertures postero-laterally on ventral surface. Caudal rami 1.5 times longer than wide, armed as in female. Appendages as in female except for antennules, maxillipeds and, fourth and sixth legs.

Antennule (Fig. 9c) 17-segmented; the last segment indistinctly 2 segmented (with 2 and 8 setae), geniculate. Segmen- tal fusion pattern as follows: 1 (I), 2 (II), 3 (III), 4 (IV), 5 (V), 6 (VI), 7 (VII), 8 (VIII), 9 (IX-XII), 10 (XIII), 11 (XIV), 12 (XV-XVI), 13 (XVII), 14 (XVIII), 15 (XIX-XX), 16 (XXIXXIII), 17 (XXIV-XXVIII). Geniculation located between segments 15 (XIX-XX) and 16 (XXI-XXIII). Segments 1-8 with 2 setae each; segment 9 with 6 setae plus an aesthetasc; segments 10 with 1 seta and 1 small spine; segment 11 with 2 setae; segment 12 with 4 setae; segments 13 and 14 with 2 setae each; segments 15 with 4 setae; segment 16 with 4 setae plus one aesthetasc, segment 17 with 10 setae. Segment 10 (XIII) reduced, partly overlapped by distal expansion of compound segment 9 (IX-XII).

Maxilliped 5-segmented (Fig. 9d), comprising short syncoxa, long basis and distal subchela consisting of 
Fig. 9 Asterocheres kervillei Canu, 1898 (male). a habitus, dorsal; b urosome, dorsal; c antennule; $\mathbf{d}$ maxilliped; e two last endopodal segments of the fist leg

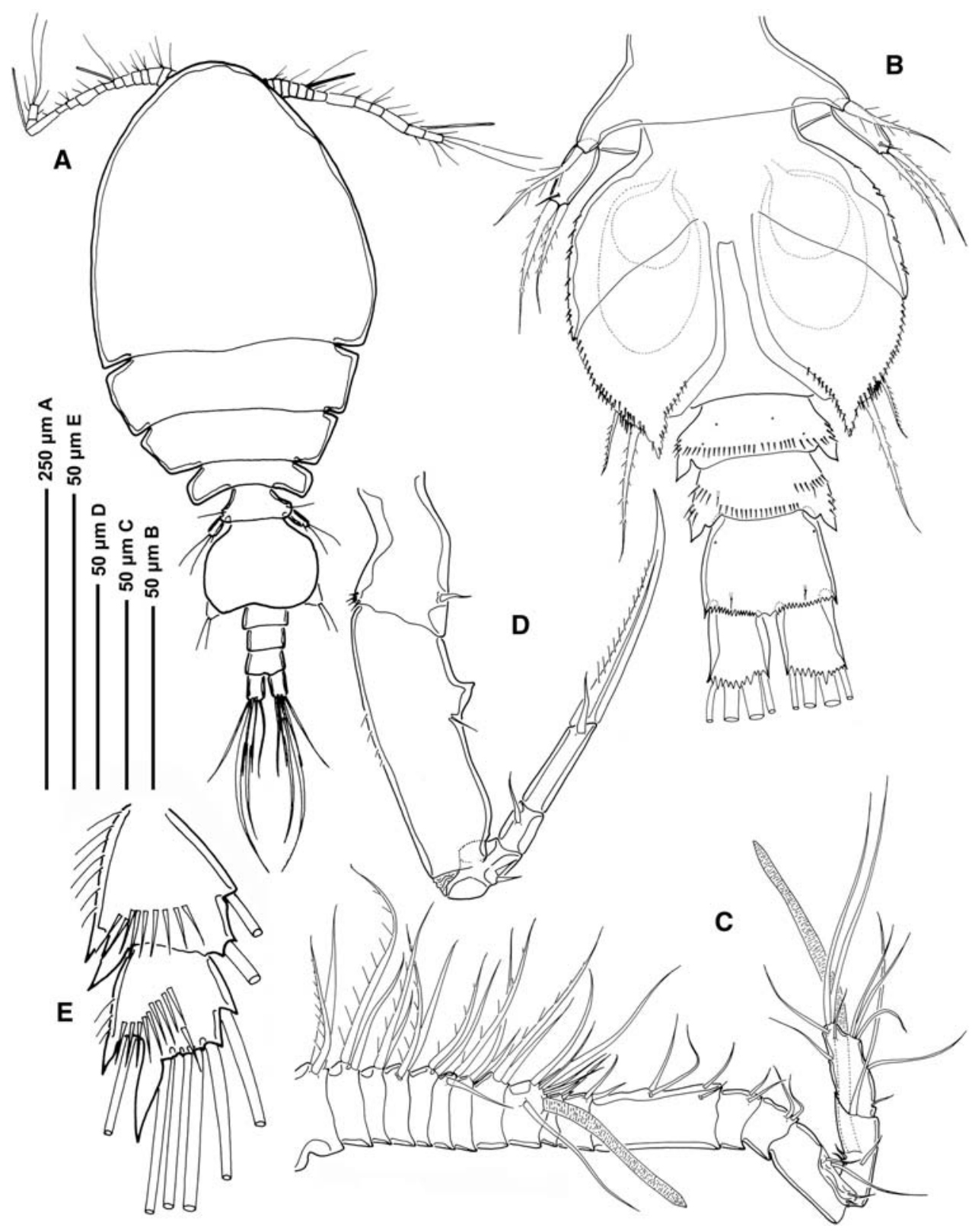

three free endopodal segments armed with distal clawlike element. Syncoxa with small inner distal seta and patch of fine spinules. Basis elongated with spinules laterally, small tooth-like process in proximal half of medial margin and setule on inner medial region. First endopodal segment bearing two naked setae and second with smooth seta. Third endopodal segment bearing recurved terminal claw plus additional apical smooth seta. Distal margin of claw provided with row of minute setules.

First leg (Fig. 9e) as for female except for the ornamentation of second and third endopodal segments. These two segments have row of spinules on distal part. Third segment with beak-like process.
Sixth leg (Fig. 9b) forming large opercular plates closing off genital apertures, armed with two plumose unequal setae and ornamented with fine spinules.

\section{Remarks}

This species was described by Canu in 1898 on the basis of specimens living freely among seaweeds in a mussel bank in Normandy. Although the original description and illustrations are very good, Canu did not make a detailed description of the oral appendages or the swimming legs. Thus, the antenna, mandible, maxillule, maxila and maxilliped were not described, although some of these appendages were showed in the illustration of the male in ventral view. 
Fig. 10 Asterocheres echinicola (Norman, 1868) (female): a oral appendages; Asterocheres latus (Brady, 1872) (female): b urosome, lateral; c caudal rami, lateral. Asterocheres kervillei Canu, 1898 (female): d caudal rami, ventral; e urosome, ventral

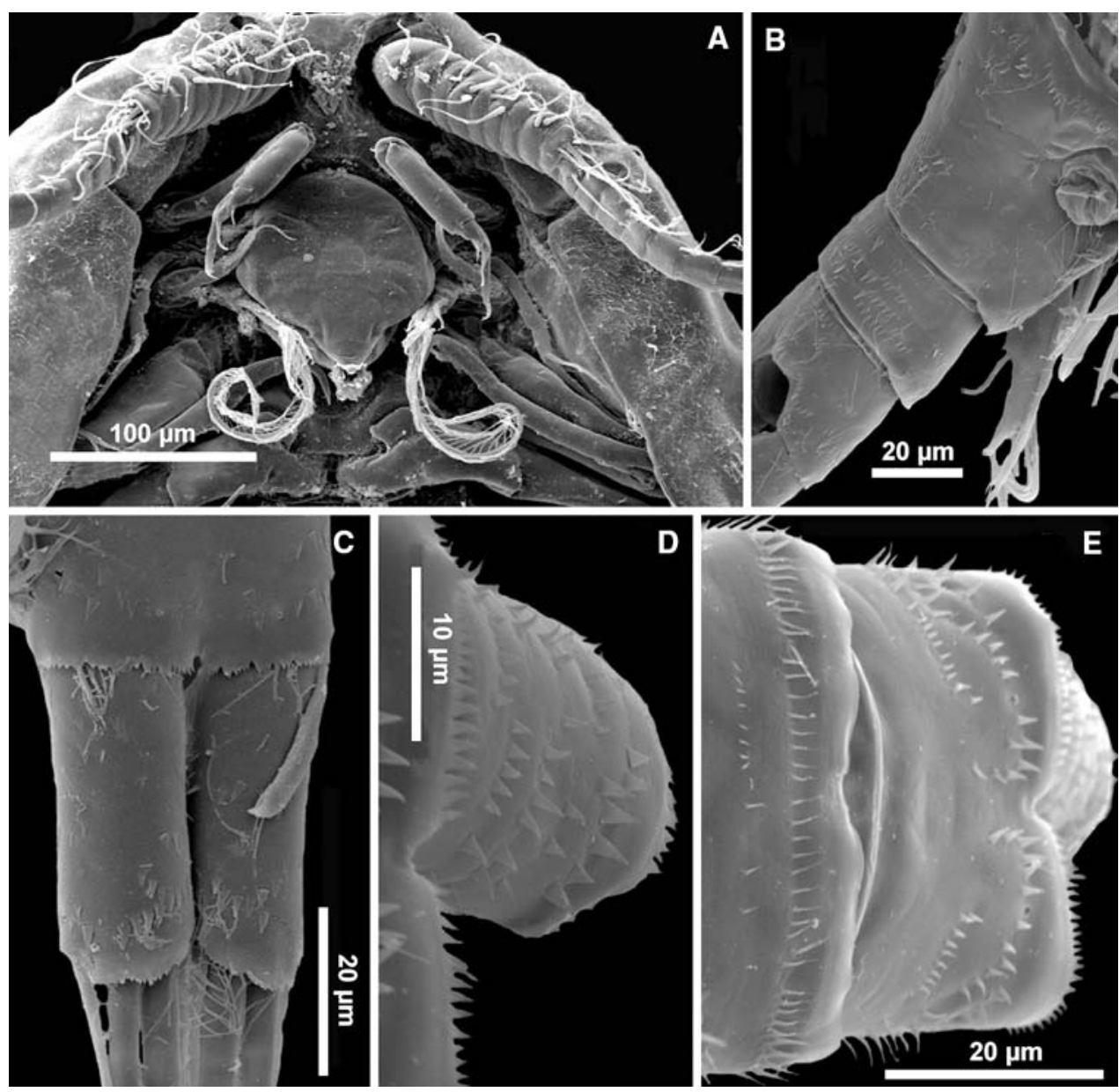

The antenna was illustrated as possessing a 2-segmented endopod; although in fact, the antenna shows a 3-segmented endopod with the third segment ornamented with setules and armed with two subterminal setae plus an apical claw. The mandibular palp has rows of spinules that did not appear in Canu's illustration. The maxillule possesses an inner and an outer lobe with five and four setules, respectively; while in the original illustration the inner lobe lacks any ornamentation and only presents four setae. The maxilla was originally described as 2-segmented without ornamentation or armature, while in fact, the maxilla is ornamented with setules and spinules in both segments and a flaccid aesthetasc-like element medially in the praecoxal portion of syncoxa. The maxilliped is 5-segmented as Canu described, but the illustration does not show the armature which is $(1,1,2,1,1+$ claw $)$.

The swimming legs for females are described and illustrated for the first time and the fifth leg which was described as bearing two terminal setae, is now redescribed with three terminal setae.

The male antennule was described as possessing $18 \mathrm{seg}$ ments. However, the re-examination of males specimens has revealed that the antennule shows 17 segments with the last segment partially divided in two segments. The sixth legs show two setae instead of the unique seta described by Canu.

Asterocheres kervillei belongs to the group of Asterocheres species possessing a 21-segmented antennule in the female and 2-segmented mandibular palp. This group consists of fourteen species: A. lilljeborgi; A. latus; A. uncinatus; A. tenuicornis; A. simulans; A. suberitis; A. tenerus; A. ellisi; A. jeanyeatmanae; A. reginae; A. flustrae; A. lunatus; A. urabensis; $A$. hirsutus and A. astroidicola.

As regards the body shape, A. lilljeborgi, A. simulans, A. jeanyeatmanae and A. reginae are characterized by having a dorso-ventrally flattened prosome in contrast with the slender oval cephalothorax present in A. kervillei (Ivanenko and Ferrari, 2003; Ivanenko, 1997; Yeatman, 1970 and Boxshall and Huys, 1994).

Johnsson in 1998 described A. lunatus as an asterocherid with a very broad prosome and the pedigerous somite 1 and 2 with extended pointed epimera which serve to separate it from A. kervillei.

As for the length of the siphon, most of these species possess a siphon that reaches to the insertion of maxillipeds, including A. kervillei. However, the siphon of A. tenerus, A. urabensis and A. hirsutus extends up to the intercoxal plate of leg 1 and $A$. astroidicola possess a 
siphon that reaches up to the leg 2 (Bandera and Conradi 2009; Kim 2004; Bandera et al. 2005).

Asterocheres tenuicornis can be easily distinguished from the rest of Asterocheres with 21-segmented antennule and the new species by its very elongated caudal rami (based on Fig. 2a of Eiselt 1965). A. uncinatus possesses only two terminal setae on the exopod of the fifth leg (Marcus and Por 1960). However, A. kervillei shows three terminal setae on the free segment of the fifth leg.

The length of the caudal rami serves to separate $A$. kervillei from the remaining species of the group, A. simulans, A. flustrae, A. ellisi, A. suberitis and A. latus. The caudal rami of $A$. kervillei are twice as long as wide. However, those of A. simulans, A. flustrae, A. ellisi, A. suberitis and A. latus are about twice as wide as long, as long as wide, only slightly longer than wide, 1.5 times longer than wide and 2.5 times longer than wide, respectively (Ivanenko 1997; Ivanenko and Smurov 1997; Hamond 1968; Giesbrecht 1899; see above for redescription of $A$. latus). The most similar species of the group is A. latus, and in fact, during 40 years these two species have been synonymous. However, the above mentioned differences are enough to separate these two species.

\section{Hosts}

Living freely among seaweeds in a mussel bank (Canu 1898) and in association with the ascidian Pseudodistoma lyrnusense Pérès, 1952 (present record).

\section{Distribution}

Atlantic.

Acknowledgments The authors are very grateful to Miranda Lowe, curator at the Natural History Museum of London, Dirk Platvoet, curator at the Zoological Museum of Amsterdam and Lutz Bachmann and Ase Wilhelmsen, curators at the Natural History Museum of the University of Oslo, for arranging the loans of the examined material.

\section{References}

Bandera ME, Conradi M (2009) Redescription of Asterocheres suberitis Giesbrecht, 1897 and A. tenerus (Hansen, 1923) (Copepoda: Siphonostomatoida), including notes on Asterocheres abyssi (Hansen, 1923) and Asterocheres intermedius (Hansen, 1923). Zootaxa (in press)

Bandera ME, Conradi M, López-González PJ (2005) Asterocheres hirsutus, a new species of parasitic copepod (Siphonostomatoida: Asterocheridae) associated with an Antarctic hexactinellid sponge. Helgol Mar Res 59:315-322

Bandera ME, Conradi M, López-Gonzalez PJ (2007) Two new asterocherid species (Siphonostomatoida: Asterocheridae) from Madeira and the Canary Islands (eastern Atlantic). Mar Biol Res 3:93-108

Barel CDN, Kramers PGN (1977) A survey of the echinoderm associates of the north-east Atlantic area. Zool Verhand 156:1-159
Bocquet C, Stock JH (1962) Some recent trends in work on parasitic copepods. Oceanogr Mar Biol Ann Rev 1:289-300

Bocquet C, Stock J, Louise F (1963) Copépodes parasites d'invertébrés des côtes de France. XV. Le probléme systématique d'Asterocheres violaceus (Claus) et d'Asterocheres minutus (Claus). Koninkl Nederl Akad Wetens 66(1):37-53

Boxshall GA, Huys R (1994) Asterocheres reginae, a new species of parasitic copepod (Siphonostomatoida: Asterocheridae) from a sponge in Belize. Syst Parasitol 27:19-33

Brady GS (1872) Contributions to the study of the Entomostraca. VII. A list of the non-parasitic marine copepods of the northeast coast of England. Ann Mag Nat Hist 4(10):1-17 pls 2-6

Brady GS (1880) A monograph of the free and semi-parasitic Copepoda of the British Island. III: 1-83, pls. 83-93. The Ray Society, London

Bresciani J, Lützen J (1962) Parasitic copepods from the west coast of Sweden including some new or little known species. Vid Medd Dansk naturh Foren 124:367-408

Canu E (1898) Note sur les copepods et les ostracodes marins des côtes de Normandie, pls 3-10. Bull Soc Amis Sci Nat Rouen (4) 33:389-422

Claus C (1889) Uber neue oder wenig bekannte halbparasitis-che Copepoden-und Ascomyzontiden-Gruppe. Arb Zool Inst Univ Wien $8(3): 1-4$

Conradi M, Bandera ME, López-González PJ (2006) The copepods associated with the coral Astroides calycularis (Scleractinia, Dendrophyllidae) in the Strait of Gibraltar. J Nat Hist 40:739-757

Eiselt J (1965) Revision und Nuebeschreibungen weiterer siphonostomer Cyclopoiden (Coepoda, Crustacea) aus der Antarktis. Sitzungsberichten der Öesterreichischen Akad Wiss Math-Natur Klasse 174:151-169

Giesbrecht W (1895) The subfamilies, genera and species of the copepod family Ascomyzontidae, Thorell: diagnosis, synonymy and distribution. Ann Mag Nat Hist 16:173-186

Giesbrecht W (1897) System der Ascomyzontiden, einer semiparasitischen Copepoden-Familie. Zool Anz 20(536):253-255

Giesbrecht W (1899) Fauna und flora des Golfes von Neapel und der angrenzenden meeres-abschnitte herausgegeben von der Zoologishen Station zu Neapel. 25. Monographie: Asterocheriden. Berlin, pp 207

Gooding RU (1957) On some Copepoda from Plymouth, mainly associated with invertebrates, including three new species. J Mar Biol Assoc UK 36:195-221

Gotto RV (1979) The association of copepods with marine invertebrates. Adv Mar Biol 16:1-109

Gotto RV (1993) Comensal and parasitic copepods associated with marine invertebrates (and whales). In: Kermack DM, Barnes RSK, Crothers JH (eds) Synopses of the British Fauna (New series). No 46. The Linnean Society of London, London, p 264

Graeffe E (1902) Übersicht der Fauna des Golfes von Triest. V. Crustacea. Arb Zool Inst Univ Wien 13(1):33-80

Hamond R (1968) Some marine copepods (Misophrioida, Cyclopoida and Notodelphyoida) from Norfolk, Great Britain. Crustaceana $1: 37-60$

Hansen HJ (1923) Crustacea Copepoda II. Copepoda Parasitica and Hemiparasitica. The Danish Ingolf-Expedition 3(7):1-92

Humes AG (1986) Sypnosis of copepods associated with asteroid echinoderms, including new species from the Moluccas. J Nat Hist 20:981-1020

Huys R, Boxshall GA (1991) Copepod evolution. The Ray Society, London, p 468

Ivanenko VN (1997) Redescription of Asterocheres simulans (Copepoda, Siphonostomatoida, Asterocheridae)-A symbiont of Suberites domuncula ficus (Spongia) from the White SeaComments of the taxonomy and ecology. Zool Zhurnal 76(10):1118-1130 
Ivanenko VN, Ferrari FD (2003) Redescription of adults and description of copepodid development of Dermatomyzon nigripes (Brady \& Robertson, 1876) and of Asterocheres lilljeborgi Boeck, 1859 (Copepoda: Siphonostomatoida: Asterocheridae). Proc Biol Soc Wash 116:661-691

Ivanenko VN, Smurov AV (1997) Asterocheres flustrae n. sp. (Copepoda: Siphonostomatoida: Asterocheridae) associated with Flustra foliacea L. (Bryozoa) from the White Sea. Syst Parasitol 38:111-130

Johnsson R (1998) Six species of the genus Asterocheres (Copepoda: Siphonostomatoida) associated with sponges in Brazil. Nauplius 6:61-99

Kim IH (2004) New species of copepods (Crustacea) associated with marine invertebrates from the Pacific Coast of Panama. Korean J Biol Sci 8:165-186

Klie W (1933) Halbparasitische Copepoden aus der Kieler Bucht. Schr Naturwiss Ver Schleswig-Holstein 20(1):12-17

Lang K (1949) On some Swedish marine semi-parasitic and parasitic copepods. Ark Zool 42A(22):1-10

Marcus A (1965) New copepoda of the Black Sea. Trav Mus Hist nat Gr Antipa 5:91-96

Marcus A, Por F (1960) Die Copepoden einer probe aus dem felsbiotop von Yalta (Krimhalbinsel). Trav Mus Hist Natur "Grigore Antipa" 2:145-163

Norman AM (1868) Shetland final dredging report. Part II. On the Crustacea, Tunicata, Polyzoa, Echinodermata, Actinozoa, Hydrozoa and Porifera. Report British Ass Advan Sci 38:295-301
Sars GO (1915) An account of the Crustacea of Norway with short descriptions and figures of all the species. Copepoda Cyclopoida. The Bergen Museum 6:81-140

Schirl K (1973) Cyclopoida siphonostomatoida (Crustacea) von Banyuls (Frankreich, Pyrénées-orientales) mit besonderer berücksichtigung des gast-wirtverhältnisses. Bijd Dierk 43(1):64-92

Scott T (1893) Report on Entomostraca from the Gulf of. Guinea, collected by John Rattray, BSc. Trans Linn Soc Lond Zool 6:1-161

Scott T (1898) Some additions to the Invertebrate Fauna of Loch Fyne. Ann Rep Fish Board Scotland 16(3):261-282

Scott T (1900) Note on some gatherings of Crustacea on board of the "Garland". Ann Rep Fish Board Scotland 18(3):382-407

Stock JH (1960) Sur quelques Copépodes asocies aux invertébrés des côtes du Rousillon. Crustaceana 1(3):218-257

Stock JH (1967) Sur trios especes de copepodes synonymes ou confondues: Asterocheres echinicola (Norman), A. parvus Giesbrecht et A. kervillei Canu (Cyclopoida, Siphonostoma). Bull Zool Mus Univ Amsterdam 1(4):31-35

Thompson IC (1889) Appendix to third Report on the Copepoda of Liverpool Bay. Proc Trans Liv Biol Soc 3:192-194

Thompson IC (1893) Revised report on the Copepoda of Liverpool Bay. Trans Liv Biol Soc 7:175-230

Yeatman HC (1970) Copepods from Chesapeake Bay sponges including Asterocheres jeanyeatmanae n. sp. Trans Am Micros Soc 89(1):27-38 